\title{
A Study of Isolated Operation of a Microgrid Configured with New Energy Generators
}

\author{
Jiro Sumita Member (NTT Facilities, Inc.) \\ Kojiro Nishioka Non-member (NTT Facilities, Inc.) \\ Yasuhiro Noro Member (Toshiba Corp.) \\ Hirofumi Shinohara Member (Toshiba Corp.) \\ Yozo Ito Member (Toshiba Fuel Cell Power Systems Corp.) \\ Masanori Yabuki Member (Toshiba Fuel Cell Power Systems Corp.) \\ Noriko Kawakami Member (Toshiba Mitsubishi-Electric Industrial Systems Corp.)
}

Keywords: microgrid, isolated operation, new energy generator, inverter, simulation, verification test

The "New Energy Plant" had been built at the Aichi EXPO. 2005 site as part of the "Demonstrative Project of Regional Power Grid with Various New Energies". This project has been promoted by the New Energy Consortium, which consists of the New Energy and Industrial Technology Development Organization and a number of private enterprises. The plant includes three types of fuel cell - phosphoric acid fuel cell (PAFC), molten carbonate fuel cell (MCFC), and solid oxide fuel cell (SOFC) - with photovoltaic power generation system (PV) and Sodium Sulfur (NaS) battery. One of the purposes of the demonstrative project is to verify supply/demand control, etc. to minimize the effect on the utility grid. Isolated operation of a microgrid is an ultimate state to be no interaction between utility grid and the microgrid. It also increases value of the microgrid.

These new energy generators are connected to the microgrid via inverter and there are no synchronous generators. There are no established techniques to startup and control voltage and frequency of such system. The authors carried out a verification test of isolated operation of the microgrid.

This paper presents the control strategies for isolated operation of a microgrid configured with some new energy generators. Simulation results of microgrid excitation, load share operation, and response for load change such as an induction motor is connected are shown. These results are reflected to the verification test condition. This paper also presents the test result of isolated operation of the microgird on Aichi EXPO. 2005.

The system had separated from utility grid, and performed stable controllability for load change for around three weeks. But total amount of load was limited because of bus voltage drop. Figure 1 shows a part of power generation results of new energy generators from 30th Sept. to 11th Oct. The microgrid was energized by a PAFC on 30th Sept. The 2nd to 4th PAFC were synchronized to the 1 st PAFC and stable load share operation was confirmed. NaS battery was connected and started operation on 1st Oct. SOFC and MCFC started power generation on 7th Oct. and 10th Oct. respectively.

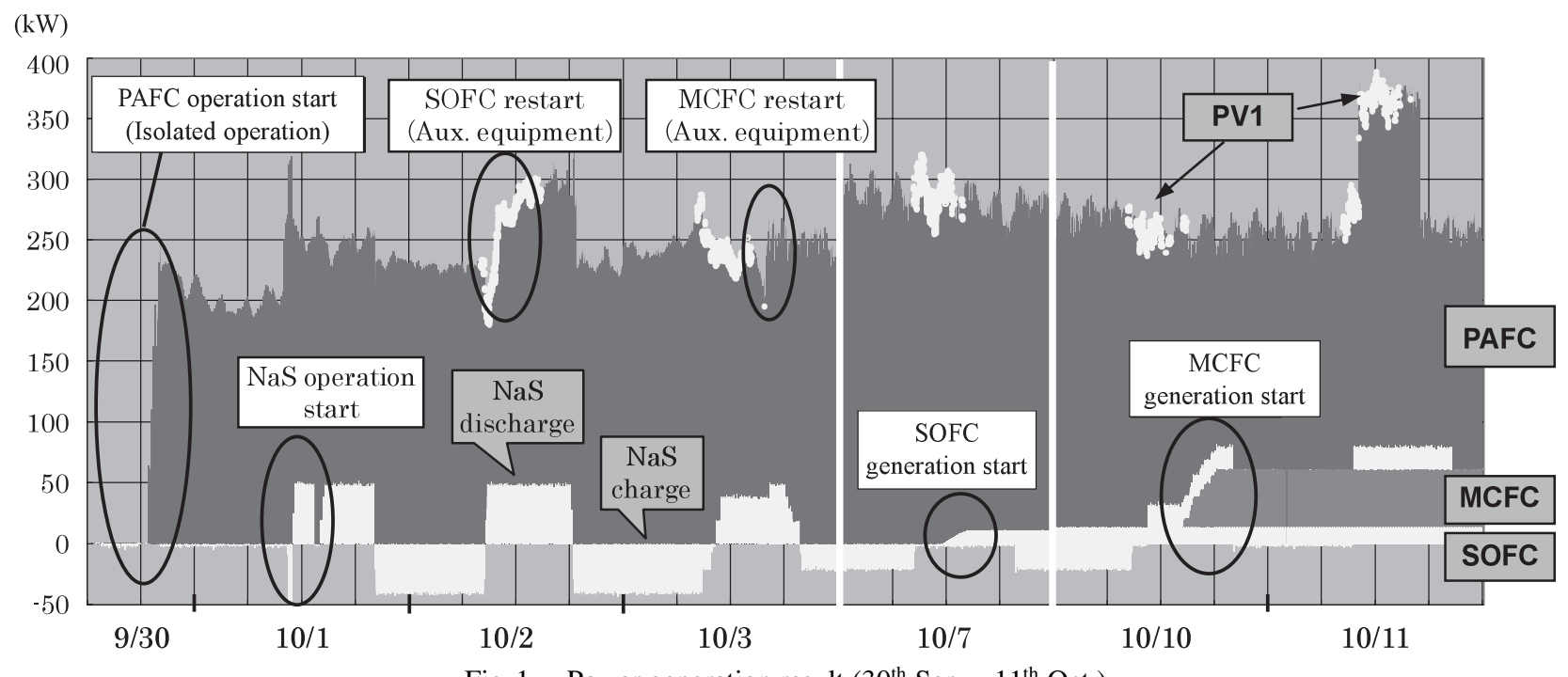

Fig. 1. Power generation result ( $30^{\text {th }}$ Sep. $\sim 11^{\text {th }}$ Oct.) 


\section{新エネルギー発電装置を用いたマイクログリッドの自立運転の検討}

$\begin{array}{lllll}\text { 正 員 角田 } & \text { 二郎 } & \text { 非会員 } & \text { 西岡宏二郎* } \\ \text { 正 員 野呂 } & \text { 康宏 } & \text { 正 } & \text { 員 篠原 裕文** } \\ \text { 正 員 伊東 } & \text { 洋三*** } & \text { 正 員 矢吹 正徳*** } \\ \text { 正 員 川上 } & \text { 紀子**** } & & & \end{array}$

\section{A Study of Isolated Operation of a Microgrid Configured with New Energy Generators}

Jiro Sumita*, Member, Kojiro Nishioka*, Non-member, Yasuhiro Noro**, Member, Hirofumi Shinohara**, Member, Yozo Ito***, Member, Masanori Yabuki***, Member, Noriko Kawakami****, Member

The "New Energy Plant" had been built at the Aichi EXPO. 2005 site as part of the "Demonstrative Project of Regional Power Grid with Various New Energies". The plant includes three types of fuel cells, photovoltaic power generation system and Sodium Sulfur $(\mathrm{NaS})$ battery. One of the purposes of the demonstrative project is to verify supply/demand control to minimize the effect on the utility grid. Isolated operation of a microgrid is an ultimate state to be no interaction between utility grid and the microgrid. It also increases value of the microgrid. These new energy generators and battery are connected to the microgrid via inverter and there are no rotating generators. There are no established techniques to startup and control voltage and frequency of such system. The authors carried out a verification test of isolated operation of the microgrid.

This paper presents the control strategies for isolated operation of a microgrid configured with some new energy generators. Simulation results of system excitation, load share operation, and response for load change such as an induction motor is connected are shown. This paper also presents the test result of isolated operation of a microgird on Aichi EXPO. 2005. The system had separated from utility grid, and performed stable controllability for load change for around three weeks.

キーワード：マイクログリッド，自立運転，新エネルギー発電装置，インバータ，シミュレーション，実証試験

Keywords: microgrid, isolated operation, new energy generator, inverter, simulation, verification test

\section{1. はじめに}

マイクログリッドは一定エリア内の電力供給において， 複数の分散型電源, 電力貯蔵装置, 電力負荷設備を様々に

\footnotetext{
*(株) エヌ・ティ・ティファシリティーズ

テ 170-0004 東京都豊島区北大塚 2-13-1 G.H.Y. ビル

NTT Facilities, Inc.

2-13-1, Kita-Ootsuka, Toshima-ku, Tokyo 170-0004

** (株) 東芝

T 183-8511 府中市東芝町 1 東芝府中事業所内

Toshiba Corp.

1, Toshiba-cho, Fuchu 183-8511

*** (株) 東芝燃料電池システム

厂 230-0045 横浜市鶴見区末広町 2-4 東芝京浜事業所内

Toshiba Fuel Cell Power Systems Corp.

2-4, Suehiro-cho, Tsurumi-ku, Yokohama 230-0045

**** (株) 東芝三菱電機産業システム

厂 183-8511 府中市東芝町 1 東芝府中事業所内

Toshiba Mitsubishi-Electric Industrial Systems Corp.

1, Toshiba-cho, Fuchu 183-8511
}

組み合わせて制御・運用することにより，電力供給システ ムとしての経済性や電力供給信頼度を向上させる需要家の ニーズに合わせた効率的な供給を行うシステムであるが, 従来検討されているシステム, 特に, 風力発電や太陽光発 電等の新エネルギーを含む場合には需給調整の困難さのた めに系統電源と連系することが前提となっている。

しかしながら, 海外での大停電発生等の社会的現象への 対応や非電化地域への新エネルギーの導入など, 系統に頼 らない自立運転が可能となることによりマイクログリッド の有用性はさらに高まるものと考える。

新エネルギーによる電源は，ほとんどがインバータによ り系統連系しており ${ }^{(1)}$, インバータの運転は基本的には周 波数や電圧は系統に依存している。少数のインバー夕連系 の電源で負荷設備に供給している場合には, 系統が停電時 等に, 需給調整が可能な電力貯蔵システムや燃料電池等に おいて 1 台のインバータを基準として自立運転を行う例も あるが, 多数台かつ異種のインバー夕連系の新エネルギー 
電源で構築されたマイクログリッドの自立運転については 実現例が無いばかりでなく，運転・制御方法に関しても確 立されたものが無い。

独立行政法人新エネルギー・産業技術総合開発機構 (NEDO 技術開発機構）の委託を受け，新エネルギーコンソーシア ムを構成する 9 事業者†が協同で，「2005 年日本国際博覧 会・中部臨空都市における新エネルギー等地域集中実証研 究」を実施している ${ }^{(2)(3)}$ 。実証研究では複数種の燃料電池, 太陽光発電等で構成される世界最大規模の新エネルギー電 源および $\mathrm{NaS}$ 電池により構成されるマイクログリッドの実 証運転に加え，自立運転試験を実施しており，これにより， 課題・知見・技術を蓄積することを目的としている。筆者 らは，自立運転に関して，上記背景を踏まえて実現のため の方策を検討してきた ${ }^{(4)}$ 。

本論文では，まず自立運転におけるインバータの制御方 法の考え方を述べ，次に，試験に先立ち，自立運転が安定 に行えること，負荷変化に対するシステムの周波数や電圧 の変動特性，モー夕起動時の過渡的な応答特性等をシミュ レーションにより把握し，試験条件に反映したのでその検 討結果を報告する。さらに，万博閉幕後の 9 月 30 日から 約 3 週間に渡って，マイクログリッド内の発電設備と負荷 の一部を用いてマイクログリッド自立運転検証試験を行っ たので，その試験結果を報告する。

\section{2. システム構成と課題}

図 1 は対象システムの構成を示すものである。4 台の PAFC (リン酸形燃料電池), 1 台のSOFC (固体酸化物形 燃料電池), 1 台の MCFC (溶融炭酸塩形燃料電池), 1 台の PV (太陽光発電) の新エネルギー電源設備と, 1 台の $\mathrm{NaS}$ (ナトリウムー硫黄) 電池, および，これらより供給される 負荷設備が含まれる。これらは, 愛知万博において運用さ れたマイクログリッドの主要な設備を含んでおり，基本的 には万博会期中の長久手日本館およびNEDO パビリオン へ100\%新エネルギーで安定して供給する観点で設備計画 され, 電力系統から切り離して自立運転の試験を行うにあ たり，事前のシミュレーションにおいてもほぼこれに対応 した構成で検討した。実際の試験時の負荷設備としては長 久手日本館 (空調・照明等 $150 \mathrm{~kW}$ ), 新エネルギー電源制 御室（空調・照明等～ $50 \mathrm{~kW}$ )，および，新エネルギー電源 設備自身の補機類（ポンプ・ヒー夕等〜 $150 \mathrm{~kW}$ ) が中心で あり，展示関係の負荷が使用できなくなったため，万博開 催期間中の電力系統連系時よりも限定した状況であった。

図 1 より明らかなように電源設備は全てインバー夕によ り系統連系しており，回転機が含まれていない。従来の新 エネルギー電源設備は系統電源またはマイクログリッド中 の回転機電源にシステムの周波数を決めてもらい, これに

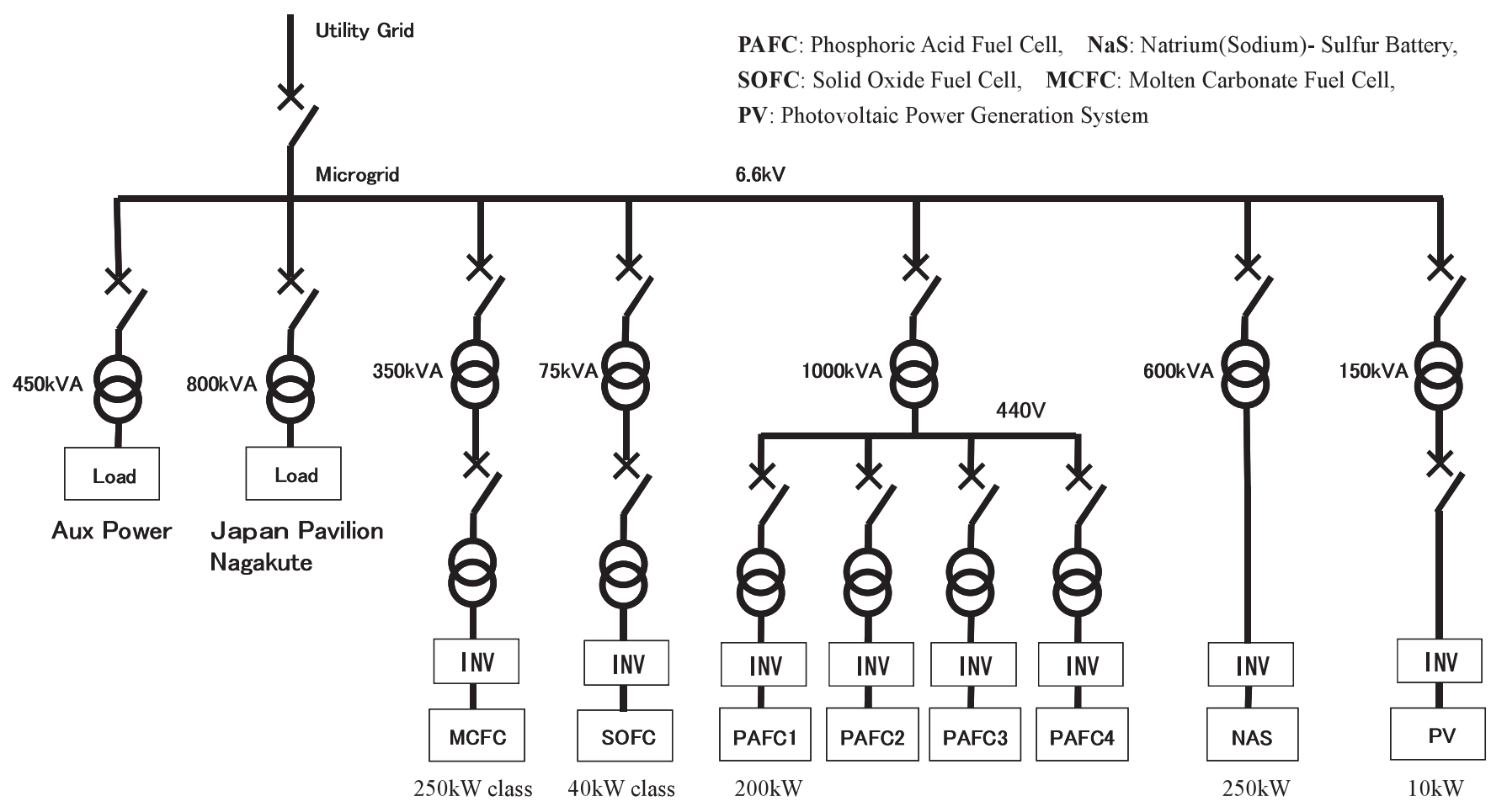

図 1 自立運転試験のシステム構成

Fig. 1. System configuration during islanding operation.

† 中部電力 (株), トヨタ自動車 (株), 日本ガイシ (株), 三菱重工 業 (株), 京七ラ (株), (財) 2005 年日本国際博覧会協会, 愛知県, 日 本環境技研 (株)，(株）エヌ・ティ・ティファシリティーズの 9 事業 者が共同で実施。 
同期して運転するのが前提となっており，本システムも万 博会期中は電力系統に連系した形で運用している。しかし ながら，自立運転時には新エネルギー電源設備が自身で周 波数を決定し，瞬時の需給バランスを確保する必要がある。

一方，停電補償などのシステムではインバータより負荷 に供給している例がある。しかし，これはインバータが 1 台（制御装置の共有により等価的に 1 台とみなせる場合も 含む）の場合か，ごく限定された構成 ${ }^{(5)(6)}$ であり，本シス テムのように複数かつ異種の独立したインバータにより構 築されたマイクログリッドの自立運転の実現例は見当たら ない。

そこで，系統電源または回転機に依存せず，複数のイン バータにより系統周波数と電圧を決めつつ，負荷の変化に 合わせて需給調整を行うことが大きな課題の一つとなる。

\section{3. 自立運転時の制御方法}

上記課題を解決するために, 本システムでは新エネルギー 電源設備のうち，負荷の変化に追従可能な PAFC を電圧制 御モードで運転し，システムの電圧・周波数を決定すると 同時に需給調整を行うこととし，その他の新エネルギー電 源設備は指令值に従って一定出力で運転する（即ち系統連 系時と同じ）方針とした。

図 2 にPAFC 1 台分の主回路構成と制御回路を示す。マ イクログリッドが系統電源と連系している場合には，図中 の GC (Grid Connect) モードで運転しており，指令として 与えられる有効電力, 無効電力に従って有効電力制御や電 流制御が動作する。

自立運転中には GI（Grid Independent）モードで運転す る。このモードでは電圧制御が選択され，PAFCの出力に よりシステムの電圧が決定される。ただし，電圧制御の制 御特性を指令值に対して偏差なく一致するような特性とす ると, PAFC 4 台間の制御誤差や主回路インピーダンスの ばらつきにより出力アンバランスが大きくなることが予想 されるので，出力変化に対して適度なスロープ特性を持た せて装置間の出力ばらつきが小さくなるような対策が必要 である。そこで，本システムでは電圧制御の部分を一般的 な PI 制御回路ではなく，比例 $(\mathrm{P})$ 項のみの制御とし，制御 ゲインを適切に設定することでこのような特性を実現して いる。

一方，システムの周波数を決定するのは位相・周波数検 出回路である。この回路は PLL（Phase Locked Loop）と 呼ばれる回路方式により系統連系時には系統側の周波数お よび位相を連続的に検出する機能を有しており，検出した 位相信号により制御回路内の電圧・電流信号を DQ 軸に座 標変換し，電圧電流制御に使用すると同時に PWM パルス 発生部で信号波の周波数を決定することは広く知られてい る(7)。本システムではこの回路の位相誤差を増幅する部分 を自立運転時には比例制御とすることにより, 出力が大き くなると位相誤差のオフセットが残り，その結果周波数偏 差が大きくなるようなスロープ特性を持たせている。

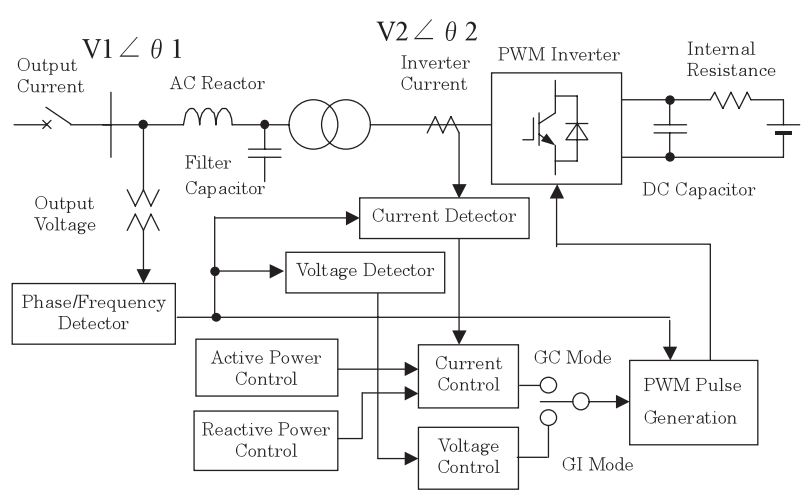

図 2 PAFC システムの構成

Fig. 2. PAFC System configuration.

Phase/Frequency Detector

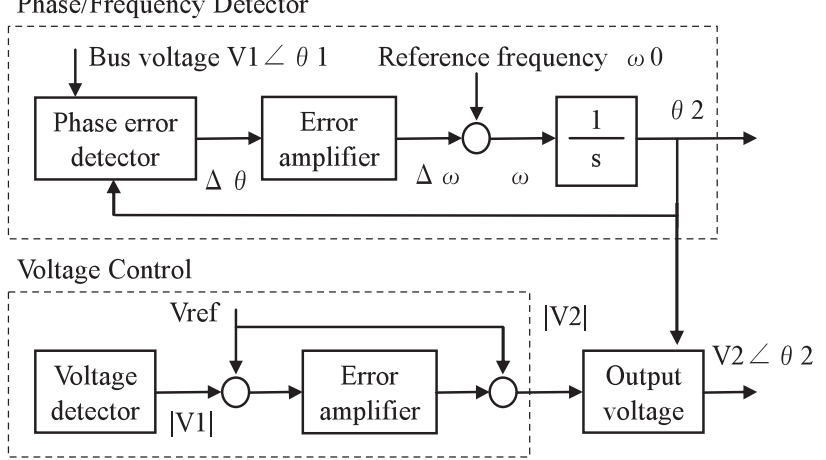

図 3 自立運転の制御方式

Fig. 3. Block diagram for Isolated Operation.

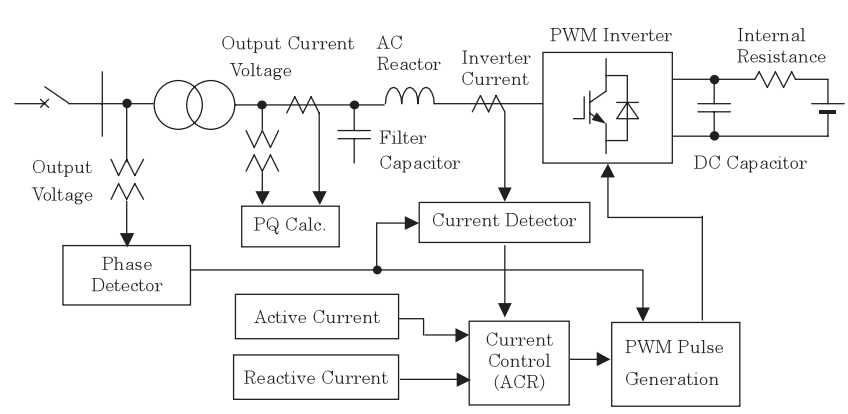

図 4 他の新エネルギー電源システムの構成

Fig. 4. System configuration for the other DGs.

この原理を図 2, 図 3 を用いて以下に説明する。図 2 に おいて，母線側の電圧を $\mathrm{V} 1 \angle \theta 1$ ，インバー夕の出力電圧を

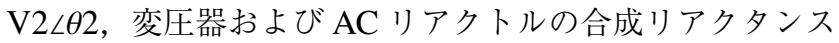
を $\mathrm{X}$ とすると, インバータが出力する有効電力 $\mathrm{P}$ は,

$$
\begin{aligned}
& P=\frac{V 1^{*} V 2}{X} \sin (\Delta \theta) \\
& \text { ただし, } \Delta \theta=\theta 2-\theta 1
\end{aligned}
$$

で表される。 $\Delta \theta$ が小さい場合には近似的に $\mathrm{P}$ と $\Delta \theta$ は比例 する。一方, 図 3 において $\theta 1$ は母線電圧位相, $\theta 2$ はイン バー夕出力電圧位相基準であるから検出した位相誤差 $\Delta \theta$ は (1) 式と対応し, 有効電力 $\mathrm{P}$ に比例する。誤差増幅を比 例制御としていることより， $\Delta \omega$ すなわち，周波数偏差も 
有効電力 $\mathrm{P}$ に比例し，制御ゲインにより傾きが決まる。こ れによって静的には回転機と同様のスロープ特性を実現し， 負荷に応じて出力を分担する並列運転が可能となる。

以上の二つのメカニズムにより負荷変動に対応しつつ電 圧（無効電力成分）と周波数（有効電力成分）の装置間の バランスを保つことを実現した。また，ここで述べた制御 方法は PAFC に限らず，電池側の負荷追従特性さえ問題な ければ，他の電源設備にも適用可能なものである。

他の新エネルギー電源設備については, 図 4 に示す主回 路構成・制御回路としてシミュレーションを実施した。

\section{4. シシミュレーション結果}

〈4・1〉 システムの起動 システムの起動はもう一つ の大きな課題である。複数台かつ異種のインバータで構成 されるマイクログリッドの始動において，一般的な電力シ ステムと同様に, 最初に 1 台の電源を起動し, 順次他の電 源設備を連系していく手順を考える。電源の連系と合わせ て負荷設備も順次増やしていくことになるが，負荷端の変 圧器を投入した場合を想定して励磁突入電流のシミュレー ション評価を行ったところ, 負荷に含まれる $300 \mathrm{kVA}$ 程度 の変圧器投入でもインバータ群の過電流耐量を超過する大 きな電流が流れることが判明した。そこで, 負荷端の変圧 器は最初から接続した状態でシステムを起動する方法につ いて検討した。最初の起動時は図 5 の網掛け部分に示すよ うに $200 \mathrm{~kW}$ の PAFC1 台で $3000 \mathrm{kVA}$ を超える変圧器を 励磁する必要がある。変圧器の残留磁束も考慮したシミュ レーションを行った結果, 図 6 に示すように 15 秒程度の 時間をかけて電圧を徐々に立ち上げるソフトスタートによ り，インバータが過電流トリップしないでシステムを起動 できることが判明した。な㧍，図 1 と図 5 で負荷設備の変 圧器容量が異なるのは, シミュレーション時点で使用可能 な負荷が確定していなかったためである。

$\langle\mathbf{4} \cdot \mathbf{2}\rangle \quad 2$ 台目以降の電源の連系 2 台目以降の PAFC は, 自身のインバー夕出力により出力変圧器を励磁後, 系統 側と同期を取って連系スイッチ（MCB）を投入することで 突流無く連系することが出来る。ここで, 電圧制御と位相・

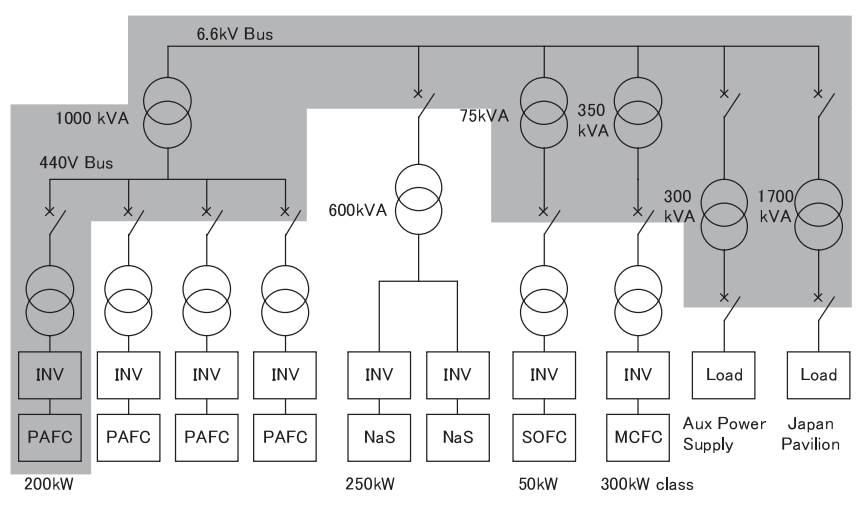

図 5 初期励磁範囲

Fig. 5. System excitation range.
周波数検出回路は先に説明したものと同一のものである。

図 7 にシミュレーション結果を示す。2 台目〜4 台目の PAFC が大きな不安定現象を発生せず連系し, かつ, 連系 と同時に負荷を均等に分担していることがわかる。4台の PAFC は起動シーケンスを除いては同一の制御回路を適用 しており，独立に運転しながら負荷分担を実現できている。 即ち, 自律的に協調を取れる方式であり, 上位の分担制御 等無しで実現できる上に，マイクログリッドの規模が大き くなっても適用可能である。

また, PAFC 以外の電源設備は, 今回は電圧制御としない ため，同じ方法で連系を行うことはできない。図 1 より明 らかなように, これらの電源設備も変圧器を有しているが, 先に述べた 1 台目の電源起動時には, 可能な限り接続する 変圧器を少なくして励磁電流を減らしたい。そこで, 負荷 および PV を除く電源設備は, 一旦自立運転で起動して変

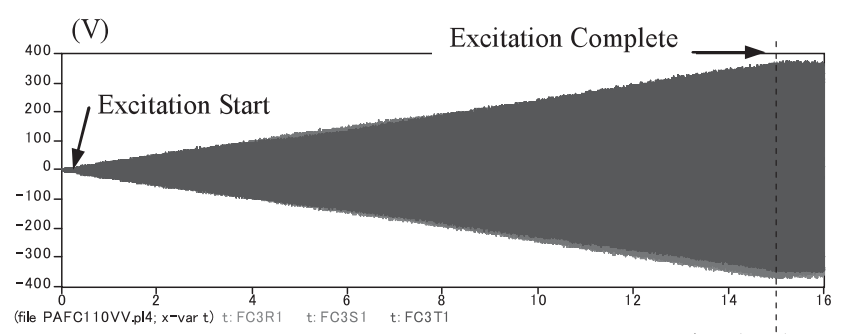

(a) 440V Bus Phase Voltage Time(sec.)

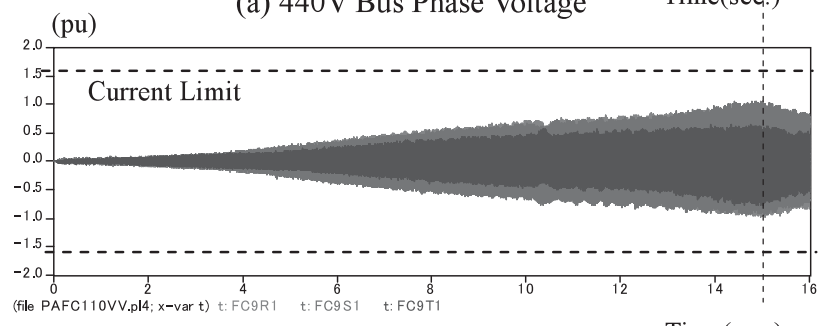

(b) Inverter Current

Time(sec.)

図 6 初期励磁シミュレーション結果

Fig. 6. System excitation simulation result.

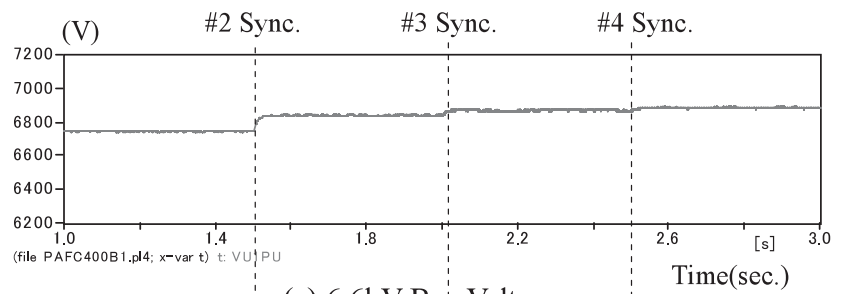

$\begin{array}{lll}(\mathrm{kW}, \mathrm{kVar}) & \text { (a) } 6.6 \mathrm{kV} \text { Bus Voltage }\end{array}$

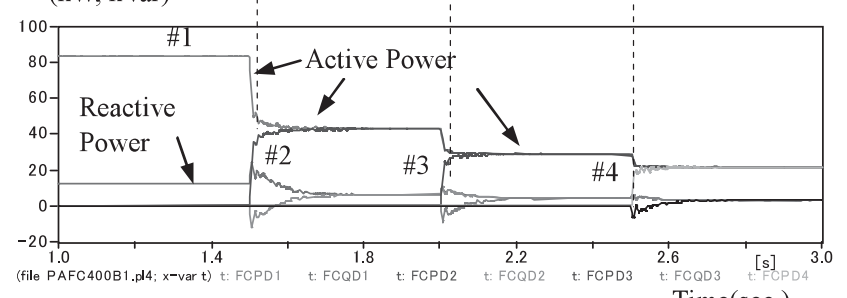

(b) PAFC Output Power

Time(sec.)

図 7 PAFC の並列運転

Fig. 7. PAFC synchronization. 


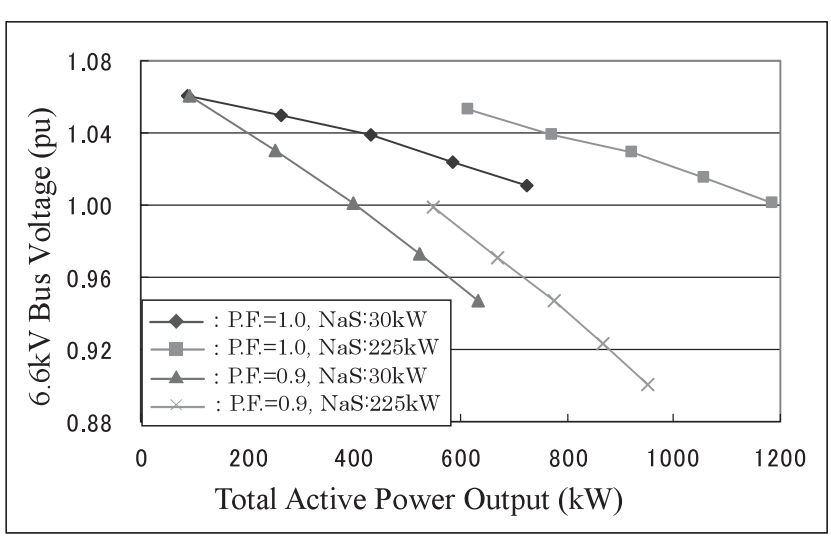

図 8 負荷変化に対する $6.6 \mathrm{kV}$ 母線電圧変化

Fig. 8. $6.6 \mathrm{kV}$ Bus voltage vs. active power output.

圧器を励磁，マイクログリッドに同期を取って連系後にイ ンバータを停止させ，制御モードを系統連系モードに切り 替えて再度起動する方法を検討した。シミュレーションで も大きな外乱は生じず，順次系統並列できることを確認し た。なお，事前シミュレーションでは NaS 電池を 2 台使用 することを想定したが評価に影響を与えるものではない。

〈4・3〉並列運転時の制御特性 新エネルギー電源設 備並列運転時の制御特性を確認するために, PAFCを 4 台, $\mathrm{NaS}$ を 台接続し，負荷の変化に対するシステムの定常的 な電圧，周波数の特性を評価した。

負荷総量の变化に対する電圧変化を解析した結果を図 8 に示す。図 8 より, 負荷力率が 1.0 の場合は, 負荷量に応じ て $\mathrm{NaS}$ 電池の出力を調整してやれば, $1200 \mathrm{~kW}$ 程度の総負 荷でも $6.6 \mathrm{kV}$ 母線電圧を $1.0 \mathrm{pu}$ 程度に維持できることがわ かる。一方，負荷力率が 0.9 と悪い場合，負荷 $600 \mathrm{~kW}$ 程度 でも既に電圧が $0.96 \mathrm{pu}$ を割り込み, $900 \mathrm{~kW}$ 超で $0.9 \mathrm{pu}$ ま で低下する。これは，保護リレーが動作するレベルではな いが, $6.6 \mathrm{kV}$ 母線から先の変圧器や配電線の電圧降下を考 えると負荷 $600 \mathrm{~kW}$ 位でも，低圧側の電圧を一般の配電系 統並みの $101 \pm 6 \mathrm{~V}$ に維持する限界と思われる。なお，電圧 変化は図 2 の電圧制御部分の制御ゲインを大きくすること により改善可能であるが，前述のように負荷分担ばらつき とのトレードオフの関係があるため，改善策適用にあたっ ては実システムにおけるデータの収集が必要である。

一方，周波数変動は PAFC の有効電力出力でほぼ決まる ため, 図 9 に示すように力率 1.0 と 0.9 の差が小さく, NaS 電池によって有効電力を供給すれば，その分周波数変動が 小さくなる。また，図 9 では周波数変化が負側のみに現れ ているが，バイアス調整により動作の中心点は調整可能な ので，例えば $\pm 0.3 \mathrm{~Hz}$ といった範囲に仕上げることも可能 である。この程度の周波数変動であればマイクログリッド 内の新エネルギー電源設備および負荷設備の運転には支障 が生じないと思われる。

$\langle\mathbf{4} \cdot \mathbf{4}\rangle$ 負荷変化時の応答特性 一般的に, モー夕始動 時に突流が流れる事は良く知られている。負荷設備の中か

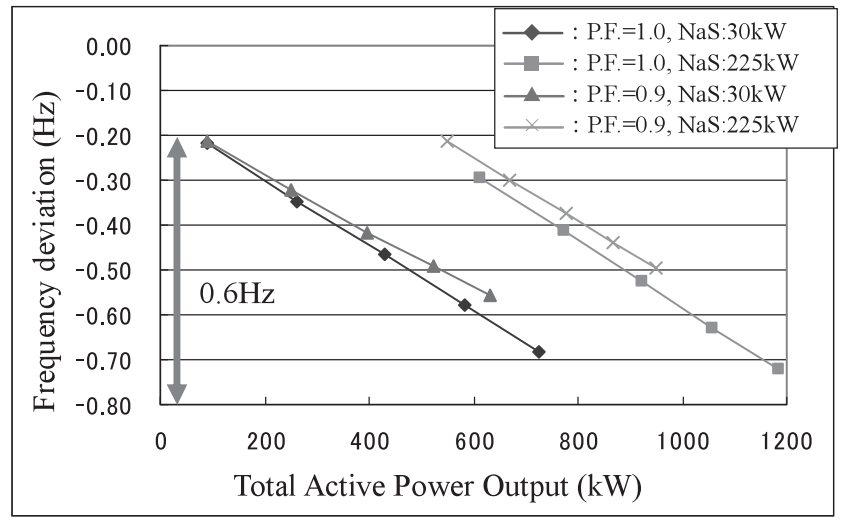

図 9 負荷変化に対する周波数変化

Fig. 9. System frequency vs. active power output.

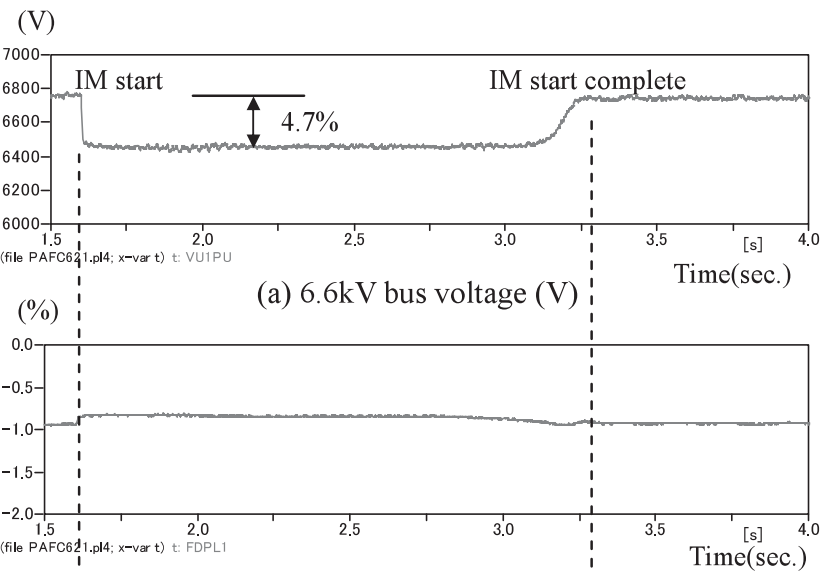

$(\mathrm{kW}, \mathrm{k} \mathrm{kar}) \quad$ (b) System frequency deviation (\%)
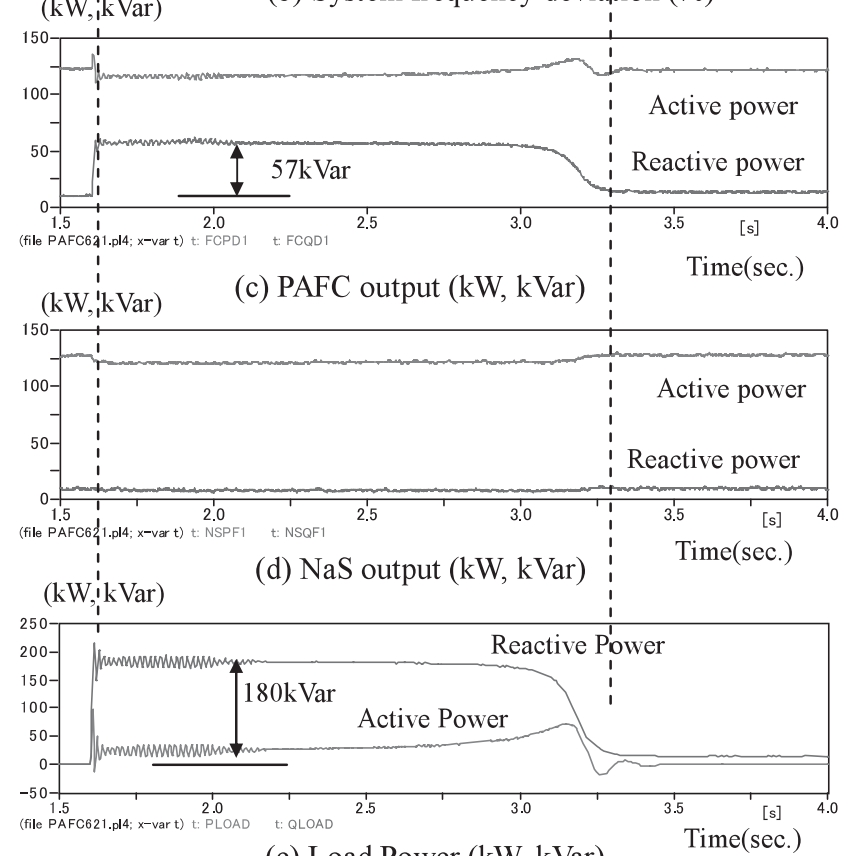

(e) Load Power (kW, kVar)

図 10 負荷変化に対する応答

Fig. 10. System response vs. load change. 


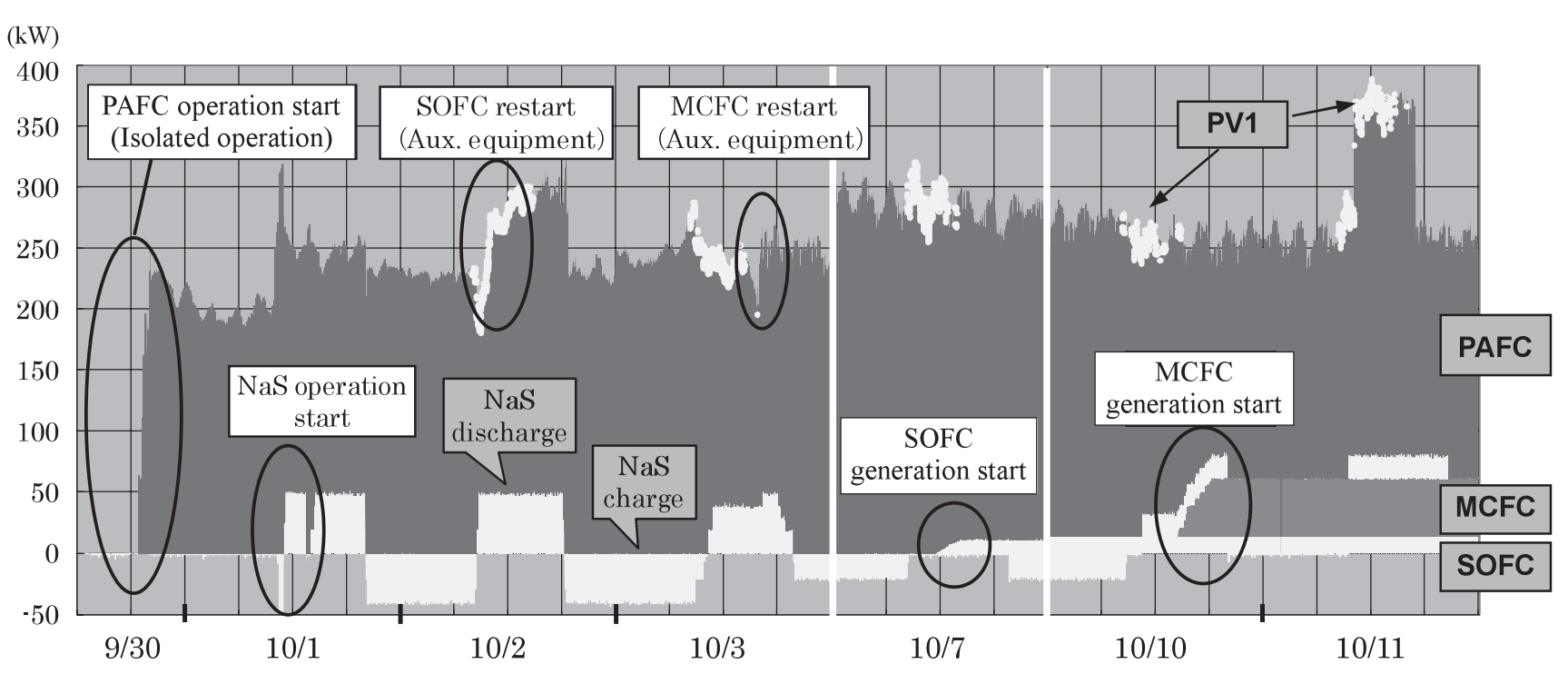

図 11 発電実績（2005 年 9 月 30 日～10月 11 日）

Fig. 11. Power generation result $\left(30^{\text {th }}\right.$ Sep. $\sim 11^{\text {th }}$ Oct. $)$.

ら最も容量が大きな電動機は $30 \mathrm{~kW} \sim 35 \mathrm{~kW}$ 程度であるの で，ここでは $40 \mathrm{~kW} の$ 電動機を例に直接始動を行なった場 合の電圧変化と周波数変化を見た。シミュレーション結果 を図 10 に示す。電圧変動を見ると，180 kVarの無効電力 変動により始動前 $6760 \mathrm{~V}$ から始動直後 $6450 \mathrm{~V}$ まで $310 \mathrm{~V}$ (4.7\%) 低下するが，許容レベルと考える。計算例では電 圧低下が 2 秒弱継続しているが，継続時間に関しては電動 機の特性や機械負荷に依存する部分が大きいため，参考程 度である。この負荷変動分は PAFC の無効電力供給の変化 として 1 台あたり $57 \mathrm{kVar}$ 程度吸収している。一方，始動 途中の電動機有効電力の増加分は小さいので, 周波数の変 動は小さい。むしろ，電圧低下により他の定インピーダン ス負荷の有効電力が減少したため, トータルの有効電力が 減少し，わずかに周波数が上昇した。

\section{5. 自立運転試験結果}

〈5・1〉 自立運転の結果概要 9月 30 日にマイクログ リッドを中部電力系統から切り離し, 一度全停電させた後, 1 台の PAFC を使用して，自立系統を確立した。その後， 10 月 19 日までの試験期間中，自立運転で安定して負荷へ 電力供給した。各発電装置の運転状況の一部を図 11 に示 す。9月 30 日は 1 台目の PAFCに 2 台目〜 4 台目の PAFC を順次並入し，4台並列での安定運転を確認した。10月 1 日より $\mathrm{NaS}$ 電池の充放電を開始，10月 2 日及び 3 日には SOFC と MCFC をマイクログリッドからの供給電力で運転 準備開始（主に昇温操作）した。さらに，10月 7 日及び 10 日にSOFCと MCFCがそれぞれ発電開始し，予定した全 ての発電装置が連系した。

$\langle\mathbf{5} \cdot \mathbf{2}\rangle$ 自立運転開始 図 12 に, 1 台目の PAFC がソ フトスタートで起動した時点の電圧・電流波形を示す。15 秒間かけて電圧が徐々に立ち上がり，合計で $3000 \mathrm{kVA}$ を 超える変圧器の励磁電流と一部負荷への電力供給を行い,

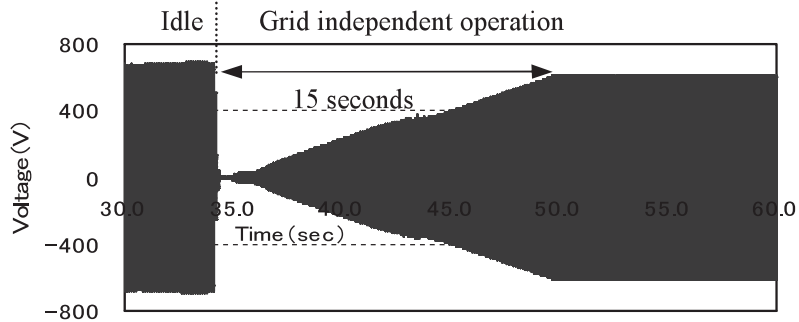

(a) Inverter output voltage

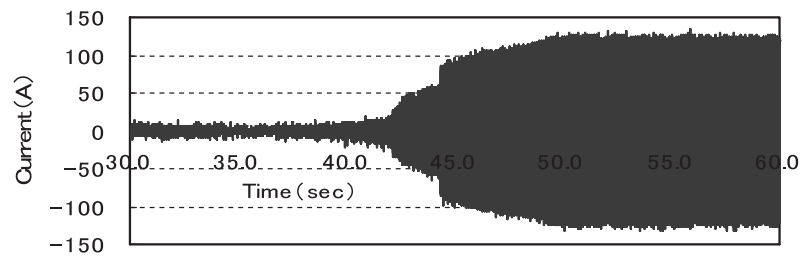

(b) Inverter output current

図 12 自立運転開始時の電圧・電流波形

Fig. 12. Inverter voltage and current on startup.

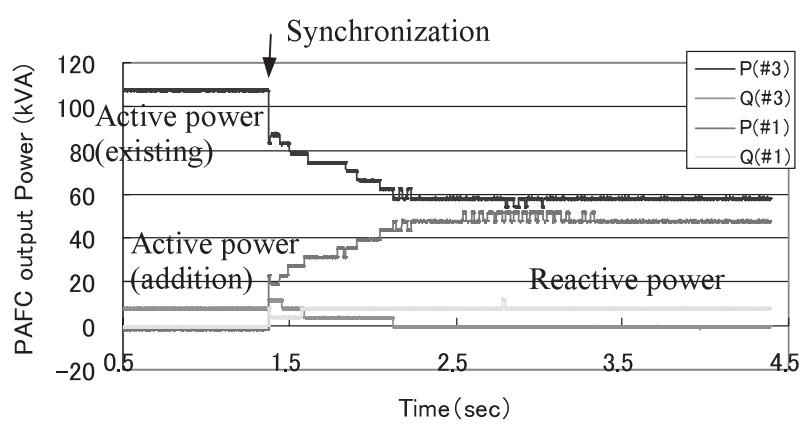

図 132 台目 PAFC の並列

Fig. 13. Synchronization of $2^{\text {nd }}$ PAFC.

自立運転を確立できた。

図 13 に2 台目の PAFC を並列したときの各々の出力電 
力を示す。 2 台目並列した瞬時に最終值の $50 \%$ 程度まで有 効電力を分担し， 1 秒弱でほぼ最終值に到達して安定して いる。また，無効電力はほとんど変化が見られていない。3 台目及び 4 台目の PAFC 並列時もほぼ同じ結果であった。 PAFC 4 台により系統電圧を確立した後， NaS 電池，太陽

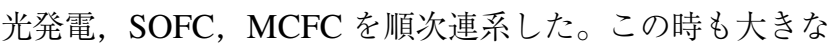
外乱は認められなかった。

$\langle\mathbf{5} \cdot \mathbf{3}\rangle$ 負荷変動時の応答

PAFC の負荷制御は，変動

$(\mathrm{kW})$
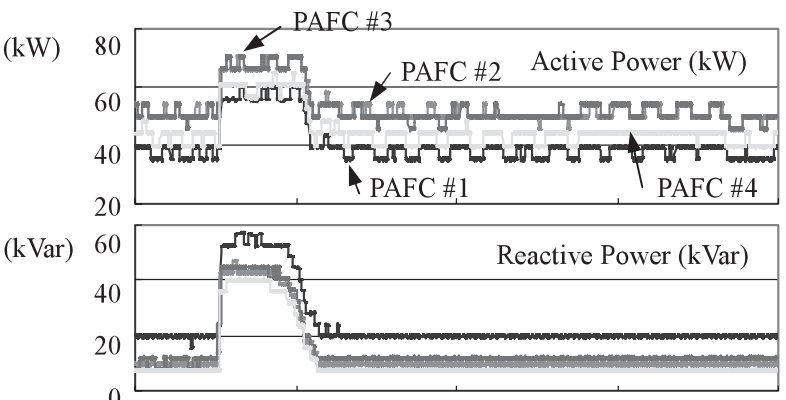

(V)

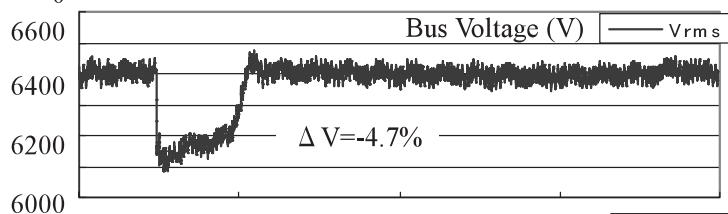

$(\mathrm{Hz})$

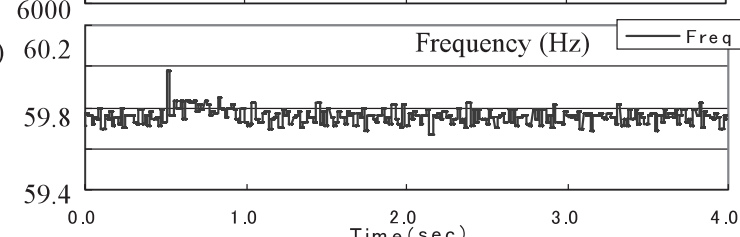

図 $1422 \mathrm{~kW}$ 電動機始動時の応答特性

Fig. 14. Response for $22 \mathrm{~kW}$ motor startup.
幅が小さい時は瞬時に，変動幅が大きい場合でも 1 秒程度 の時定数で追従することから, 本試験期間中, ヒーター等 の頻繁な負荷変動に対して問題なく応答できた。

非線形負荷の代表としてポンプ負荷 $(22 \mathrm{~kW})$ 起動を行っ

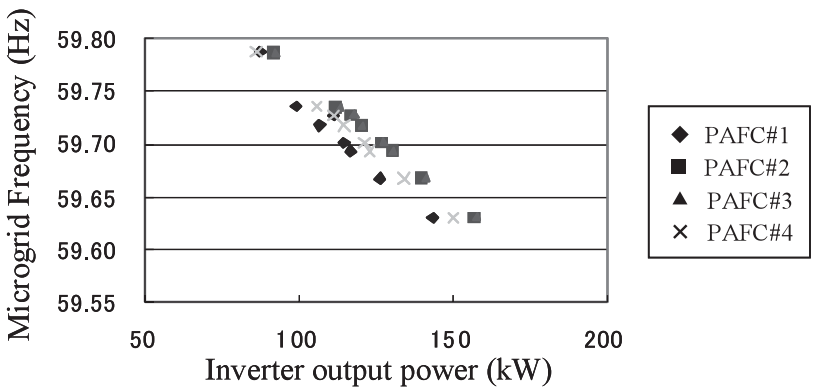

図 15 PAFC\#1 から\#4 の発電端出力と 周波数の関係

Fig. 15. Grid frequency vs. active power of four PAFC's.

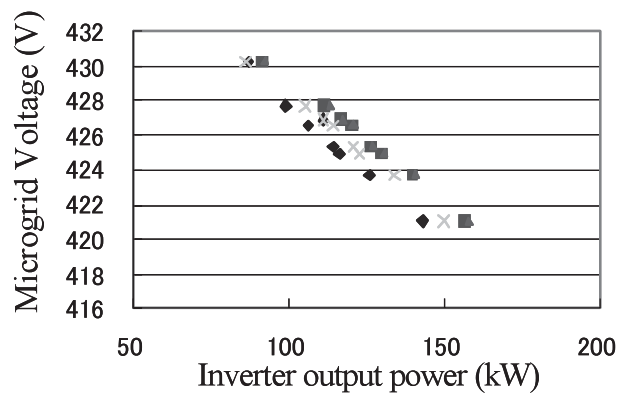

- PAFC\#1

- PAFC\#2

$\triangle \mathrm{PAFC \# 3}$

$\times$ PAFCH4

図 16 PAFC\#1 から\#4 の発電端出力と 電圧の関係

Fig. 16. Grid voltage vs. active power of four PAFC's.
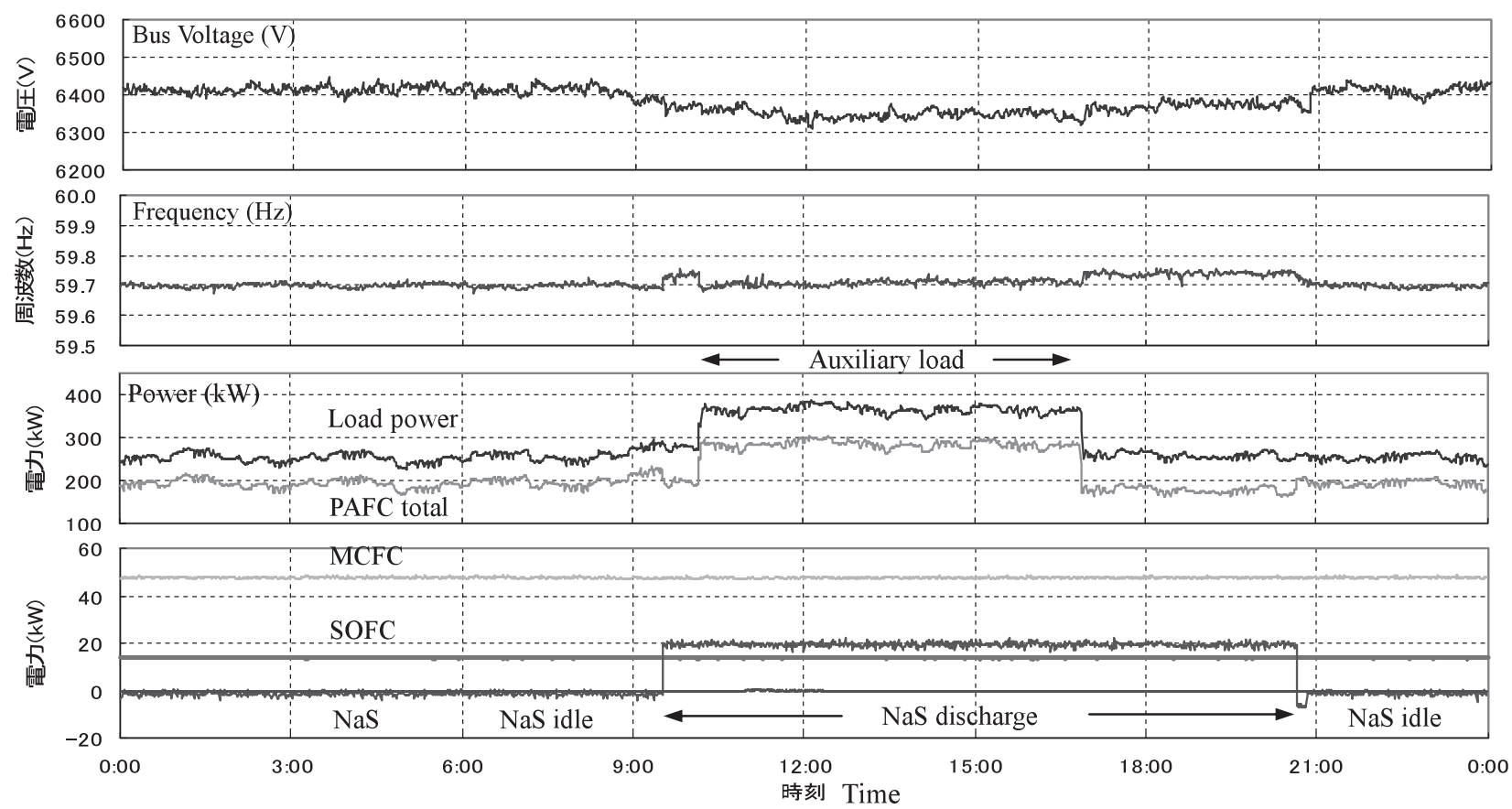

図 17 電力品質 (2005 年 10 月 11 日の電圧 ·周波数)

Fig. 17. Power Quality (Voltage and Frequency on $11^{\text {th }}$, Oct.). 
た時の波形を図 14 に示す。電圧が 0.5 秒程度低下したが, 低下レベルは約 5\%で，他の負荷への影響は無かった。

このときの PAFC の有効電力, 無効電力の出力分担と, 周波数を図 14 に合わせて示す。PAFC 4 台がそれぞれ出力 を瞬時に増加して，電力を供給している。また，周波数は ほとんど変化がないことが分かる。

〈5・4〉 電力品質 $\mathrm{PAFC}$ は負荷分担のために電圧と周 波数を変化させる制御を行っていることから，負荷の変動 に応じて, 基準となる電圧と周波数が変化する。図 15 に PAFC\#1 から\#4 のインバータ出力と系統周波数の関係を, 図 16 にインバー夕出力と電圧の関係を示す。なお，この時 の負荷は力率 1 の同一条件のものである。この結果から, 出力の増加に応じて周波数, 電圧がともに低下するという 制御特性に応じた変化となって抢り, 各インバータ出力間 のばらつきも小さいことがわかる。周波数変化については, 変動が最大でも $-0.4 \mathrm{~Hz}$ 程度であり, 負荷設備および電源 設備への影響は生じなかった。電圧変化については, 出力 増加に伴う低下傾向が大きく，マイクログリッド内負荷へ の影響が懸念された為, 定格 $-5 \%$ 程度で出力制限を行った。

図 17 に, 1 日を通しての電圧や周波数の変動例の状況を 示す。電圧は $6350 \mathrm{~V}$ 程度, 周波数は $59.7 \mathrm{~Hz}$ 程度に維持さ れ，負荷への電力品質面での影響は見られなかった。

\section{6. 考 察}

〈6・1〉自立運転開始時 シミュレーション結果の図 6 と試験結果の図 12 を比較すると, 試験結果では励磁電流成 分がほとんど流れていない。これは，事前シミュレーショ ンでは励磁電流が最大となる変圧器残留磁束の組み合わせ を考慮したが，実際にはそれほど厳しい条件とはならなかっ たためと推定する。

〈6・2 2 台目以降の電源の連系シミュレーション結 果の図 7 と試験結果の図 13 を比較すると, 試験結果では 並列瞬時に $100 \%$ 負荷分担せず，一度最終值の $50 \%$ 程度ま で分担し, その後 1 秒弱で最終值に到達している。これは, シミュレーションでは電池内部や補機の応答特性を考慮し てないためと推定される。ただし，これらの違いは，自立 運転の評価には影響を及ぼさない。

$\langle 6 \cdot 3\rangle$ 電圧・周波数の制御特性試験結果とシミュ レーションでは, 負荷の力率や観測点が異なり, 定量的な 比較はできないが両者とも負荷の増加に応じて周波数及び 電圧が低下する特性が得られた。また, 図 15 , 図 16 より, インバータ間の出力アンバランスも小さいことがわかる。

なお，力率の悪い負荷が多量に接続されることが予想さ れる場合には，電圧低下対策を別途検討する必要がある。

$\langle 6 \cdot 4\rangle$ 負荷変動時の応答 シミュレーション結果の 図 10 と試験結果の図 14 を比較すると, 無効電力変動が $57 \mathrm{kVar}$ 抢よび $35 \mathrm{kVar}$ の負荷変化に対して同じ $4.7 \%$ の電 圧低下が発生している。試験結果では初期電圧が低いので, 電流変化としては大きかったことも原因として考えられ る。電圧変動面では直接始動方式の電動機容量は今回程度
（PAFC 総容量の3〜5\%）がほぼ限界と考えられ，さらに大 きな容量の電動機が負荷となる場合には始動時の突流対策 が必要となる。周波数変動は両者とも小さく良好である。

\section{7. まとめ}

本論文では, 複数の新エネルギー電源設備で構成される マイクログリッドの自立運転に関し，インバータの制御方 法の考え方を述べた。次に, シミュレーション解析を行っ た結果，以下を確認できた。

（1）停電状態から自立運転を確立する手順を決定した。

(2) 複数台, 異種のインバー夕連系で構成されるマイ クログリッドを安定に運転できる。

（3）負荷変化に対する周波数変動や電圧変動は許容で きるレベルと思われる。

（4）小容量であればモー夕起動などの過渡時でも電圧・ 周波数変動は許容できる。

さらに, 新エネルギー発電装置と負荷から構成された大 規模マイクログリッドを系統から切り離し, 自立運転検証 試験を実施し, 以下の成果を得た。

（1）複数台の異種インバータを並列運転し，限定した 負荷であるがマイクログリッドを 20 日間安定に運転した。

（2）負荷変動に対してPAFCが追従して, 安定運転した。 今回検証したシステムにより, 環境性に優れた新エネル ギー発電装置を用い，より高効率なマイクログリッドシス テム実現への可能性が高まった。本実証試験の結果, マイ クログリッド自立運転の実用化, 普及のための貴重なデー 夕を蓄積すると共に, 課題・知見を得ることができた。電 圧制御性や保護の考え方などが，今後のシステム検討にお いてポイントになると思われる。

おわりに，本検討を実施するに当たり多大なる協力をい ただいた NEDO 技術開発機構および新エネルギーコンソー シアム関係者に感謝の意を表します。

(平成 18 年 2 月 27 日受付, 平成 18 年 6 月 2 日再受付)

\section{文献}

(1) CIGRE: "Modeling new forms of generation and storage", CIGRE Task Force 38.01.10, Report No.185 (2001)

(2) H. Nemoto: "New Energy System Demonstrated in The 2005 World Exposition, Aichi, Japan”, IEEJ J., Vol.124, No.8 (2004-8) (in Japanese) 根本 宏:「「愛・地球博」で実証展示する新エネルギーシステム」, 電学誌, 124, 8 (2004-8)

(3) The Investigation Special Committee of the Electric Power System Technique for Effective Use of the Dispersed Generation: "Electric Power System Technique for Effective Use of the Dispersed Generation", Technical Report, IEE Japan, No.1025 (2005-6) (in Japanese)

分散型電源有効活用のための電力系統技術調査専門委員会:「分散 型電源有効活用のための電力系統技術」, 電気学会技術報告, No.1025 (2005-6)

(4) J. Sumita, K. Nishioka, Y. Noro, H. Shinohara, Y. Ito, M. Yabuki, and N. Kawakami: "A Study of Islanding Operation of a Microgrid Configured with Several Inverters", The Papers of Joint Technical Meeting on Power Engineering \& Power Systems Engineering, IEE Japan, PE-05-114/PSE-05-121 (2005-9) (in Japanese)

角田二郎·西岡宏二郎·野吕康宏·篠原裕文·伊東洋三·矢吹正德・川上 紀子:「複数のインバータで構成されるマイクログリッドの自立運転の 
検討」, 電気学会電力技術／電力系統技術研資, PE-05-114/PSE-05-121 (2005-9)

(5) K. Tabe, T. Miyakoshi, Y. Hayashi, and T. Ise: "Power Exchanging Control between Quality Control Centers in FRIENDS-Controlled Characteristics during Load Change-", Proc. of the Annual Conference of Power and Energy Society, IEE Japan (2004-8) (in Japanese)

多部顕史・宮越貴史・林 祐輔・伊瀬敏史：「FRIENDS における電 力改質センター間の電力融通制御一負荷变化時の特性一」, 平成 16 年電気学会 B 部門大会, No.279 (2004-8)

(6) K. Kawasaki, K. Iwabu, T. Iima, and S. Hayashi: "Dispersed Autonomous Control for a Small Power Grid System", Proc. of the Annual Meeting of IEE Japan, No.6-006 (2005-3) (in Japanese) 川崎憲介·岩部功一・飯間孝仁・林 茂彦 : 「小規模電源の自律分散 制御について」, 平成 17 年電気学会全国大会, No.6-006 (2005-3)

（7）町田武彦：直流送電工学, 東京電機大学出版局 (1999)

角 田二郎（正員） 1968 年 2 月 25 日生。1 1990 年 3 月九州大

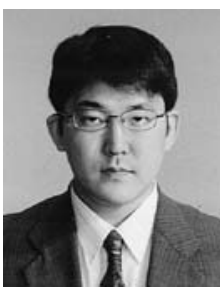
学大学院工学研究科卒業。同年 4 月日本電信電話 (株) 入社。1995 年 (株) NTT ファシリティーズ 出向。設備遠隔監視システムの開発をへて, 2003 年よりエネルギー制御システムの開発に従事。現 在, 研究開発本部パワーシステム部門主任研究員。

西 岡 宏二郎 （非会員） 1977 年 7 月 29 日生。 2003 年 3 月大

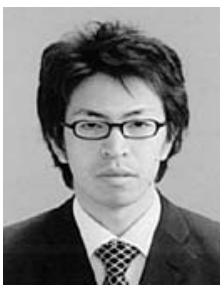
阪市立大学大学院工学研究科卒業。同年 4 月 (株) NTT ファシリティーズ入社。2004 年よりエネル ギー制御システムの開発に従事。現在，研究開発 本部パワーシステム部門所属。

野呂康 宏

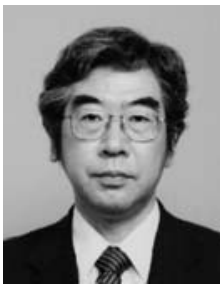

（正員） 1957 年 6 月 23 日生。1982 年 3 月東北 大学大学院電気工学科修士課程修了。同年 (株) 東芝入社。現在，同社電力・社会システム技術開 発センターに抢いて，電力システムの解析および 変換器応用システムの研究開発に従事。工学博士。 2003 年電気学会論文賞。IEEE 会員。
篠 原 裕 文 (正員) 1958 年 1 月 31 日生。1 980 年 3 月筑波

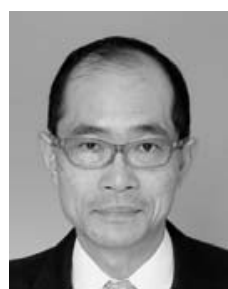
大学自然学学類 (物理) 卒業。同年 4 月 (株) 東 芝入社。プラズマ核融合実験装置，電池電力貯蔵 装置，太陽光発電の開発・システム設計に従事。

伊東 洋 三（正員） 1955 年 12 月 20 日生。 1980 年 3 月横浜

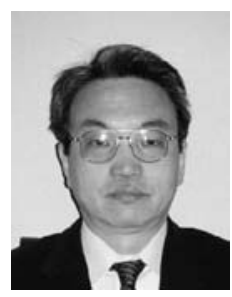
国立大学大学院工学研究科修士課程電気工学専攻 修了。同年 4 月（株）東芝入社。主として燃料電 池発電システムの電気系の開発に従事。現在，東 芝燃料電池システム（株）に勤務。

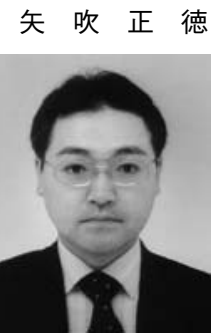

（正員） 1968 年 1 月 17 日生。1994 年 3 月東京 工業大学理工学研究科応用物理学専攻修士課程修 了。同年 (株) 東芝入社。燃料電池の開発に従事。 現在，東芝燃料電池システム（株）プラント技術 部主務。

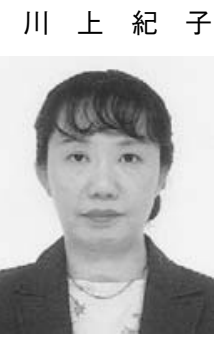

(正員) 1959 年 6 月 17 日生。 1982 年 3 月上智 大学理工学部物理学科卒業。同年 (株) 東芝入社。 現在，東芝三菱電機産業システム（株）において， パワーエレクトロニクス応用システム製品の開発 に従事。2000 年電気学会電気学術振興賞進歩賞 受賞。技術士（電気電子部門）。日本技術士会会 員。IEEE 会員。 